\title{
RESENHAS
}

REVIEWS

\section{CURSO DE DIREITO SANITÁRIO - A PROTEÇÃO DO DIREITO À SAÚDE NO BRASIL}

\author{
Fernando Aith \\ Editora Quartier Latin, São Paulo, 2007
}

Maria Célia Delduque ${ }^{(*)}$

O livro Curso de Direito Sanitário - a proteção do direito à saúde no Brasil, do professor Fernando Aith, preenche uma lacuna existente no mercado editorial de uma publicação que aborde, de maneira didática, o Direito Sanitário enquanto área do conhecimento e ramo do Direito.

Leitura obrigatória a todo aquele interessado no Direito Sanitário e na saúde pública, a obra faz conviver harmoniosamente em seu texto, o rigor conceitual do Direito com elementos de conteúdo sanitário, proporcionando uma leitura reflexiva e de inestimável aprendizado.

Com o propósito de definir os contornos do campo de estudo, o autor formula alternativas para o paradigma formal do positivismo jurídico, restrito à análise estrutural do ordenamento jurídico e da relação existente entre suas normas, confrontando-o com as representações sociais de saúde, para construir, conforme suas palavras, "o conjunto de normas jurídicas que disciplina as ações e serviços públicos e privados de interesse à saúde, visando à efetivação do direito à saúde".

Ao tratar da abrangência da área de estudos, principalmente no Capítulo VI, Aith disserta sobre as funções regulatórias do Estado, bem como

(*) Advogada, pesquisadora da Fundação Oswaldo Cruz, especialista em Direito Sanitário pela Faculdade de Saúde Pública - Universidade de São Paulo (FSP-USP) e doutoranda em Saúde Pública na USP. E-mail: <delduque@fiocruz.br>. Recebido em 21.9.07. 
sobre a função condicionante e/ou restritiva do Direito Sanitário, as quais garantem acesso universal e igualitário às ações e serviços de saúde.

Com fortes tintas sanitárias, o autor disserta sobre as conferências e conselhos de saúde e a iniciativa popular dos projetos de lei de interesse da saúde. O pesquisador inova ao apresentar o leitor com a noção de advocacy em saúde, atribuindo-lhe função de fonte indireta do Direito Sanitário.

Aqui, fazemos um destaque especial ao capítulo dos princípios do Direito Sanitário. Considerando a existência de um conjunto ordenado e lógico de princípios jurídicos voltados à promoção, proteção e recuperação da saúde, bem como o fato de que a Constituição da República (e o Direito Sanitário) enaltece os princípios da proteção da dignidade humana, liberdade e igualdade e equidade, Aith defende que a conjunção de todos estes princípios deve nortear, não apenas o arco normativo infraconstitucional, mas também ações, projetos e programas de governo e sociedade.

Neste mesmo capítulo, o autor aborda também os princípios ditos decorrentes do Direito Sanitário, como o da responsabilidade sanitária, precaução e outros.

Com conhecimento sobre o que se convencionou chamar de Direito Médico, o autor agrega ao seu livro discussões no campo da relação médico/ paciente, fazendo um paralelo do discurso teórico-normativo sobre os códigos médicos do Brasil e da França (país na vanguarda destes estudos) e propiciando também reflexões no alcance da ética e da bioética, quando enfrenta temas como consentimento livre e esclarecido; doação e transplantes de tecidos, órgãos e partes do corpo humano; pesquisa com células-tronco embrionárias; segredo médico; fim da vida e o direito de morrer dignamente.

No Capítulo IX, o leitor e o estudante têm a descrição da legislação pertinente ao tema do Direito Sanitário. O autor não se descuidou de nenhuma fonte normativa específica da saúde. Desde a legislação internacional até a legislação esparsa e infralegal da saúde de âmbito nacional, passando pelas fontes não específicas, encontra-se na obra uma minuciosa descrição do arcabouço legal sanitário, em que são destacados os principais atos normativos pertinentes à proteção do direito à saúde. Ainda discorre sobre a regulação em saúde, explicando a necessária distinção entre regulação e regulamentação, o que todo operador do direito deve conhecer.

Necessário ressaltar passagem da obra que põe fim a uma longa discussão doutrinária: a construção dos fundamentos afirmativos do Direito Sanitário, como ciência autônoma. O autor considera o Direito como a tradução normativa da vontade popular e apresenta o sistema normativo da saúde como ciência, mostrando a conexão direta com o contexto social ao qual pertence. Com isso, faz lembrar o marco fundamental do direito à saúde estabelecido em 1988 pela sociedade brasileira e finaliza sua linha de pensamento afirmando que o Direito Sanitário não pode ser compreendido ape- 
nas como um simples composto de legislação e jurisprudência, mas como uma ciência que reúne em si a vontade coletiva da sociedade.

O autor ainda acrescenta a esta conceituação, a característica transversal difusa do Direito Sanitário e mostra que, para além de seu próprio domínio normativo, o Direito Sanitário reúne, na sua complexidade, aspectos relacionados com outros ramos do Direito, aspectos esses que, direta ou indiretamente, relacionam-se com a saúde e dialogam permanentemente, com a Medicina, a Sociologia, a Administração Pública, a Filosofia e outros. 